\title{
Pengajaran Kosakata Bahasa Inggris Melalui Active Learning
}

(Penelitian Tindakan Kelas di kelas 1 SDN Mulyasari 1, Bandung)

\author{
Tri Agustini Solihati \\ Universitas Perjuangan \\ Email:try_leocps@yahoo.co.id
}

\begin{abstract}
This study was focused on the progressive in increasing the quality of students' vocabulary mastery based on the specific tpics such as color, type of food and beverage, buman body, and family members. The material was conveyed through the implementation of Active Learning in the first Grade students of SDN Mulyasari 1, Bandung. This research was conducted into two cycles. The results obtained in the first activity cycle consisted of the teachers' activities in implementing active learning was about $80 \%$ and the amount of class athmosphere was $65.25 \%$. Meanwhile, the evaluation of student learning activities on the assignment sheet reached the average 7.74, 8.78 formative test, and analysis of the vocabulary teaching reached $75 \%$. Meanwhile, in the second cycle, the results obtained by teachers' activity was $90 \%$ and $89.25 \%$ for class atmosphere. The average value obtained by students during the assignment sheet is 8.06 , the average value of formative test reached 8.96, and the analysis of vocabulary teaching was 85\%. Based on the results above, it was clear that the implementation of active learning in mastering English vocabulary would help students in remembering or even mastering that vocabulary. This achievement was inseparable from the use of instructional media and attractive teaching methods for learners.
\end{abstract}

Keywords: vocabulary, active learning, dassroom action research

\section{Pendahuluan}

Wallace (1987:1) menyebutkan bahwa kosakata adalah aspek yang paling penting dalam bahasa. Quirk (1990: 127) juga menjelaskan bahwa kosakata merupakan kumpulan kata-kata pada sebuah bahasa, kosakata ini tentunya menjadi bagian yang begitu vital pada penyampaian sebuah pesan. Artinya dapat kita simpulkan bahwa kesuksesan seseorang dalam mempelajari sebuah bahasa, baik itu bahasa ibu, bahasa nasional, bahkan bahasa asing dalam hal ini bahasa Inggris harus dibekali dengan penguasaan kosakata yang baik. Karena sudah barang tentu kemampuan ini akan berpengaruh terhadap keterampilan berbahasa yang lain; keterampilan berbicara, mendengarkan, menulis, dan membaca.

Vol. 1 No. 1, 2016
Pada saat itu mata pelajaran bahasa Inggris menjadi muatan lokal di wilayah Bandung. Tertera pada kurikulum 1994 bahwa pelajaran bahasa Inggris pertama kali diberikan di tingkat sekolah dasar sebagai bagian dari muatan lokal. Peserta didik pada jenjang ini biasanya cenderung memiliki ketertarikan untuk mengetahui dan mempelajari hal baru. Namun ada satu hal yang penting untuk diingat, bahwasanya anak-anak pada usia ini akan membangun pemahaman mereka berdasarkan pengalaman dan menjadi seorang peniru. Oleh karena itu, memperkenalkan bahas Inggris sejak dini diharapkan mampu membangun ketertarikan mereka untuk mempelajari bahasa Inggris lebih jauh lagi pada jenjang yang lebih tinggi. 
Sayangnya realita yang ada, prestasi siswa masih di bawah KKM (Kriteria Ketuntasan Minimal) yang pada saat itu cenderung berada pada angka yang rendah, yaitu 60. Sangat miris tentunya, melihat kenyataan yang ada bahwa generasi muda kita masih memiliki penguasaan Bahasa Inggris yang lemah. Padahal mereka masih harus belajar mata pelajaran ini di setiap tahunnya selama kegiatan belajar berlangsung. Artinya jika fenomena tersebut tidak terselesaikan, paling tidak tiga aspek akan terkena dampak fenomena ini. Aspek psikologi, siswa akan kehilangan motivasi belajar. Sudah barang tentu, seumur hidupnya mereka akan diselimuti kehawatiran dan meyakini bahasa Inggris sebagai mata pelajaran yang sulit dipahami. Lebih jauh lagi, mereka mungkin saja kehilangan rasa hormatnya terhadap para guru. Yang paling buruk, tentunya mereka tidak lagi bersedia untuk pergi ke sekolah. Dampak berikutnya sudah barang tentu akan memasuki ranah akademik. Kesulitan belajar yang tiada akhir akan mereka hadapi, padahal mempelajari bahasa Inggris tidak akan berhenti pada pendalaman kosakata, melainkan mampu memahami struktur dan tata bahasanya, serta menguasai keterampilannya. Yang terakhir adalah aspek sosial, pada kehidupan sehari-sehari ada kalanya mereka berada pada situasi atau lingkungan yang menyampaikan informasi dalam bahasa Inggris, maka pemahaman yang lemah terhadap bahasa ini akan mempersulit kehidupan sosialnya.

\section{Mihalyi Csikzantmihalyi}

menyebutkan bahwa konsentrasi merupakan kekuatan mental dan emosional. Konsentrasi yang mendalam akan membawa seorang pembelajar pada situasi yang disebut flow. Flow adalah kondisi ketika seseorang begitu terhanyut pada kegiatan yang sedang dilakukan, sehingga waktu yang berlalu tidak terasa. Flow ini akan lebih mudah dialami oleh seseorang ketika mengalami situasi yang disebut dan-rea atau dengan kata lain "serius menyenangkan". Active learning pada konsepnya akan mempersembahkan kegiatan yang serius dan menyenangkan. Dengan harapan, siswa akan terbantu untuk tetap mempertahankan konsentrasinya ketika belajar, meningkatkan keinginan belajar, dan mengatur suasana sekitar untuk mencapai flow (Hollingsworth, 2008: 2).

Hopkins pada Basrowi (2008: 51b) menekankan bahwa menjadi seorang pengajar, tidak hanya dituntut untuk dapat menguasai dan menyampaikan materi di depan peserta didiknya dengan baik, tapi juga harus mampu mengobservasi kegiatan yang sudah berlangsung, sehingga pengajar mampu menemukan masalahmasalah yang terjadi di lapangan. Dengan harapan pengajar dapat melakukan tindakan langsung untuk memperbaiki kegiatan belajar yang kurang efektif menjadi lebih baik, melatih dirinya untuk senantiasa mengontrol pengembangan profesi melalui latihan pengambilan keputusan secara profesional. Kemampuan tersebut sejalan dengan konsep Penelitian Tindakan Kelas (PTK). Hopkins (1993) menyatakan bahwa PTK adalah bentuk dari refleksi diri untuk meningkatkan kegiatan sosial dan pendidikan, pemahaman terhadap kegiatan itu sendiri, serta situasi dimana kegiatan tersebut dilakukan. Maka kegiatan PTK ini menurut Kurt Lewin memiliki empat komponen; perencanaan, tindakan, observasi, dan refleksi (Basrowi, 2008:27).

Berdasarkan pejelasan di atas, juga dilatar belakangi status penulis sebagai seorang pengajar, maka penulis tertarik untuk melakukan sebuah pengembangan melalui PTK. Sehingga membawa penelitian ini pada judul "Pengajaran Kosakata Bahasa Inggris melalui active learning". 
Penelitian ini dilakukan di kelas 1 SDN Mulyasari 1, Bandung.

\section{Kajian Teori}

\section{Pengajaran Bahasa di Sekolah Dasar (SD)}

\section{a. Pengertian Pengajaran Bahasa}

Salah satu cara utama dalam kegiatan mendidik adalah mengajar. Sudjana (2009: 10\&29) menyatakan bahwa mengajar adalah sebuah kurikulum operasional yang terjadi ketika ada interaksi antara peserta didik dan lingkungan belajar yang dikelola oleh seorang pendidik untuk mencapai tujuan mengajar. Bahkan definisi lain disampaikan juga bahwa mengajar merupakan sebuah proses; mengelola proses, mengatur lingkungan atau suasana di sekitar peserta didik agar mampu menumbuhkan dan memotivasi mereka terlibat pada proses pembelajaran. Maka lebih jauhnya lagi mengajar diartikan sebagai proses memberikan nasihat atau bantuan kepada peserta didik pada proses pembelajaran.

Pengajaran bahasa menurut Jarvis (1985:49) dipahami sebagai proses mentransfer bahasa kepada pembelajar yang ditopang oleh metodenya, buku ajarnya, atau tata bahasanya yang diyakini sebagai faktor penting pada proses pembelajaran. Alwasilah

(1997:125)

menambahkan bahwa pengajaran bahasa itu tidak dapat dipisahkan dari pembelajaran bahasa yang akan mencapai tujuan instruksional dan membentuk karakter peserta didik. Artinya dapat dipahami bahwa prinsip dari pengajaran harus berhubungan dengan prinsip oembelajaran yang berdasar pada kebutuhan peserta didik dan karakteristiknya.

\section{b. Pengertian Sekolah Dasar}

Di Indonesia, jenjang pendidikan dikelompokkan menjadi tiga tahapan; 6 tahun di Sekolah Dasar (SD), 3 tahun di Sekolah
Menengah Pertama (SMP), dan 3 tahun di Sekolah Menengah Atas (SMA). Pada UU Guru dan Dsen (2006:66) bab IV, pendidikan dasar, ayat 17 disebutkan bahwa (1) pendidikan dasar merupakan jenjang pendidikan yang menjadi pijakan pendidikan menengah, (2) pendidikan dasar disebut Sekolah Dasar (SD) dan Madrasah Ibtidaiyah (MI) atau nama lain yang sederajat. Pada jenjang berikutnya disebut Sekolah Menengah Pertama (SMP) dan Madrasah Tsanawiyah (MTs) atau istilah lain yag sederajat.

Pendidikan dasar yang tersedia pada sekolah dasar bertujuan untuk menyiapkan kemampuan peserta didik dalam membaca, menulis, dan berhitung yang biasa kita sebut "calistung" serta membekali pengetahuan dasar dan keterampilan yang bermanfaat untuk mereka dan sejalan dengan perkembangannya, yakni untuk menyiapkan mereka untuk melanjutkan studi pada jenjang menengah pertama.

\section{c. Pengajaran Bahasa di Sekolah Dasar (SD)}

Pengajaran bahasa di Sekolah Dasar (SD) akan sangat berbeda dengan kegiatan pengajaran di SMP atau SMA, karena aktifitas ini harus disesuaikan dengan karakteristik dan kondisi psikologi peserta didik. Mustafa (2002) menekankan bahwa aktifitas belajar pada jenjang ini akan memposisikan guru sebagai teman bermain, berbicara, bernyanyi, bermain peran, atau permainan lainnya. Oleh karena itu pembelajaran bahasa asing pada jenjang ini paling tidak bisa mengikuti langkah-langkah yang disebutkan Pahin \& Power (1990), yaitu:

- Awali kegiatan dengan menghapal namanama peserta didik;

- Buat dan sepakati aturan belajar sejak awal;

- Gunakan bahasa ibu ketika memberikan perintah, jika dianggap sulit; 
- Selalu memastikan bahwa peserta didik masih fokus pada kegiatan yang berlangsung;

- Mengelompokkan peserta didik secara acak sehingga mereka tidak hanya belajar dan beriteraksi dengan teman baiknya;

- Berkeliling kelas untuk membantu, memastikan bahasa, dan mengontrol aktifitas yang sedang dilakukan;

- Biarkan peserta didik bergerak bebas;

- Pilihlah materi dan kegiatan yang sesuai;

- Jadikan kegiatan belajar bahasa Inggris sebagai sesuatu yang menyenangkan. Hal ini dilakukan guna menumbuhkan dan menanamkan citra positif terhadap bahasa Inggris;

- Ajaklah peserta didik untuk bernyanyi, bermain, dan bersenang-senag;

- Berikan penjelasan yang jelas sehingga mereka yakin dengan apa yang dikerjakan;

- Perbanyak melakukan pengulangan dan latihan;

- Atur dan ketahuilah dengan baik segala sesuatu yang akan dilakukan; dan

- Jadilah sosok yang kreatif, mampu merencanakan kegiatan yang berkesan dan bervariasi.

(Suyanto, 2003: 7-8)

\section{Kosakata Bahasa Inggris \\ a. Pengertian Kosakata}

Oxford English Dictionary (1995:461) menyediakan beberapa pengertian kosakata. Di antaranya kosakata didefinisikan sebagai sejumlah kata dalam sebuah bahasa, kata-kata yang digunakan oleh manusia, dan sekelompok kata yang dilengkapi dengan pengertiannya yang disimpan di bagian belakang sebuah buku digunakan untuk pengajaran bahasa asing. Wallace (1987:1) menyebutkan bahwa kosakata adalah aspek yang paling penting dalam bahasa.
Dapat disimpulkan bahwa kosakata merupakan bagian vital yang harus dikuasai jika seseorang berkeinginan untuk sukses dalam mempelajari bahasa asing. Bahkan Wallace (1987:9) juga memaparkan bahwa penguasan kosakata dalam jumlah besar akan lebih menunjang komunikasi dibandingkan dengan pemahaman tata bahasa dan strukturnya.

Terkait dengan hal tersebut, maka Quirk dan Stein (1990:108) menyarankan para pembelajar bahasa asing untuk selalu memperkaya kosakata mereka, menemukan kata yang tepat untuk mewakili ide yang ingin disampaikan, dan menyadari benar bahwa memperkaya kosakata merupakan kebutuhan yang berkelanjutan dalam kehidupan.

\section{b. Posisi Kosakata dalam Pembelajaran Bahasa Inggris}

Setiap bahasa sudah barang tentu memiliki kosakatanya sendiri. Bagaimana pun ketika seseorang berkeinginan untuk menguasai sebuah bahasa, maka kosakata lah yang menjadi dasarnya. Tidak akan pernah seseorang menguasai bahasa, kecuali jika orang tersebut memiliki penguasaan yang baik terhadap kosakatanya. Wallace (1987:2) menyebutkan bahwa mempelajari bahasa asing dasarnya adalah mempelajari kosakatanya. Gagal menemukan kata yang tepat untuk mengungkapkan sebuah pemikiran, ide, atau bahkan mengekspresikan diri merupakan pengalaman yang paling menyedihkan ketika berbicara bahasa asing.

Sederhana saja untuk memahami konsep berbahasa dalam komunikasi. Pembicara tinggal memilih kata sebagai media penyampai pesan, mengupayakan pendengar bisa menerima rangsangan dan memahami informasi yang dimaksud oleh pembicara. Tetapi komunikasi ini menjadi sangat kompleks, bahkan terbilang tidak mungkin terjadi, jika pembicara tidak memiliki 
kosakata yang tepat pada bahasa itu. Oleh karena itu, memperkaya kosakata menjadi sebuah kebutuhan dan proses yang berkelanjutan bagi setiap pembelajarnya. Sehingga begitu disadari, mempelajari bahasa Inggris sebagai bahasa asing dirasakan sebagai sebuah kegiatan yang berproses lambat. Jaminan dari penguasaan kosakata adalah kemudahan penguasaan keterampilan berbahasa; mendengarkan, berbicara, membaca, dan menulis.

\section{c. Teknik Mengajar Kosakata}

Ada beberapa teknik yang harus diperhatikan dengan seksama oleh seorang guru sebelum mengembangkan pengajaran kosakata. Hal tersebut harus diawali dengan menelaah prinsip pengajaran di bawah ini, seperti yang disampaikan Wallace (1987:27):

\section{- Tujuan}

Guru harus selalu memperhatikan tujuan dari pengajaran kosakata. Segala sesuatu yang disampaikan harus sesuai dengan kosakata yang diajarkan.

- Jumlah

Guru harus menentukan berapa banyak kosakata baru yang akan diajarkan. Ketika sudah dipelajari, pastikan kosakata tersebut sering digunakan dalam komunikasinya. Sehingga guru bisa menentukan jumlahnya, 5-7 kosakata baru misalnya. Hal ini tentunya dipengaruhi oleh banyak faktor, seperti kondisi kelas atau pembelajar itu sendiri. Jika terlalu banyak mempelajari kosakata baru dikhawatirkan akan menjadi pengalaman yang membingungkan, menjenuhkan, dan membuat frustrasi.

- Kebutuhan

Guru harus mampu memilih kosakata yang tepat, sesuai dengan tujuan kegiatan, bahkan materi itu sendiri. Sangat memungkinkan bagi seorang guru, dalam hal ini berperan juga sebagai informan, untuk bisa membawa siswa pada sebuah situasi komunikasi dan memperoleh kosakata yang diperlukan.

- Pengulangan

Jarang sekali kita sebagai pembelajar bahasa asing mampu mengingat kosakata baru yang hanya kita dengar satu kali. Artinya pengulangan itu perlu dilakukan sampai guru bisa memastikan target kata yang diajarkan sudah diserap dengan baik oleh para peserta didik. Cara yang paling sederhana untuk memastikannya adalah dengan mengevaluasi pemahaman kosakata mereka dengan arti yang tepat.

- Penyampaian yang bermakna

Pembelajar harus memperoleh pemahaman yang menyeluruh terkait dengan kosakata yang diajarkan. Oleh karena itu, pemaknaan yang tepat, rujukan yang sesuai menjadi keharusan untuk menghindari pemahaman yang ambigu.

- Kondisi

Sesuaikan suasana belajar dengan materi atau kosakata yang akan diajarkan.

- Penjelasan berbasis konteks

Adakala kosakata baru itu menjadi hal yang sulit dipahami. Sehingga alangkah baiknya jika guru mampu memilih padanan kata yang sesuai dengan kosakata yang dimaksud.

Salah satu aspek yang paling berpengaruh atas kesuksesan kegiatan belajar mengajar adalah teknik mengajar yang digunakan oleh guru. Allen (1983: 9) dalam bukunya "Technique in Teaching Vocabulary" menyebutkan beberapa teknik mengajar, yaitu:

a. Aturan

Hal pertama yang harus dilakukan ketika mempelajari bahasa adalah mendengarkan dan mematuhi aturan. Karena peserta didik yang patuh aturan akan melakukan peran 
penting dalam mempelajari kosakata. Tidak akan sulit bagi seorang guru untuk mengajarkan sebuah kosakata ketika peserta didik sudah memusatkan perhatiannya.

b. Objek nyata

Arti sebuah kata dapat disampaikan melalui gambar, akan tetapi menggunakan objek nyata akan lebih baik. Objek nyata yang dimaksud adalah apapun benda yang ada di sekitar ruang belajar atau benda yang bisa dibawa ke dalam kelas.

c. Pengalaman berkomunikasi

Langkah kegiatan pegajaran kosakata adalah sebagai berikut:

- Guru menyampaikan sebuah topik tentang kehidupan di luar angkasa dalam beberapa kalimat.

- Siswa diberi tahu bahwa mereka akan dibacakan sebuah cerita tentang pengunjung dari luar angkasa. Mereka diinstruksikan untuk membuat sebauah gambar tentang pengunjung tersebut berdasarkan deskripsi guru.
- Guru dan siswa berdiskusi tentang hasil menggambar siswa dan model yang dimiliki guru.

\section{d. Ruang Lingkup Kosakata Bahasa Inggris di Kelas 1 SD}

Banyak sekali kosakata yang harus diajarkan di SD. Akan tetapi berdasarkan penjelasan di atas, siswa SD harus belajar sesuai dengan kondisi psikologinya. Mereka harus belajar bahasa berdasarkan objek nyata, khususnya bagi siswa kelas 1 . Karena mereka juga baru saja mampu menguasai bahasa ibu mereka, yaitu Bahasa Indonesia. Berdasarkan buku ajar yang digunakan, Actuve English, kosakata yang harus diajarkan terdiri dari 13 unit. 7 unit pertama tersebar pada kegiatan di semester 1, dan 6 unit tersisa dipelajari pada semester 2 .

Sebaran Kosakata

\begin{tabular}{|c|l|l|}
\hline Unit & \multicolumn{1}{|c|}{ Topik } & \multicolumn{1}{c|}{ Kosakata } \\
\hline 1 & My name is Pedro & A B C D E F G H I J K L M N O P Q R S T U V W Y Z \\
\hline 2 & Let's count & One, two, three, four, five, six, seven, eight, nine, ten \\
\hline 3 & Things in our begs & $\begin{array}{l}\text { Pencil, pen, eraser, ruler, pencil case, notebook, glue, coloring } \\
\text { pencils, markes, scissors }\end{array}$ \\
\hline 4 & Fruits & $\begin{array}{l}\text { Mango, banana, apple, melon, star fruit, orange, grape, kiwi, } \\
\text { guava, sour soup, pineapple }\end{array}$ \\
\hline 5 & My house & $\begin{array}{l}\text { Living room, bedroom, kitchen, dining room, bathroom, garage, } \\
\text { terrace, garden }\end{array}$ \\
\hline 7 & My dassroom & $\begin{array}{l}\text { Chairs, table, chalk, picture, globe, whiteboard, text book, } \\
\text { blackboard, ruler, eraser }\end{array}$ \\
\hline
\end{tabular}




\begin{tabular}{|c|l|l|}
\hline Unit & \multicolumn{1}{|c|}{ Topik } & \multicolumn{1}{c|}{ Kosakata } \\
\hline 8 & Our school & $\begin{array}{l}\text { Library, dassroom, teacher room, headmaster room, hall, school } \\
\text { yard, canteen, restroom }\end{array}$ \\
\hline 9 & Animals & $\begin{array}{l}\text { Cat, dog, hen, sheep, cow, bird, fish, rabbit, duck, horse, cock, } \\
\text { buffalo }\end{array}$ \\
\hline 10 & Colors & $\begin{array}{l}\text { Red, yellow, blue, green, pink, purple, orange, black, white, } \\
\text { brown }\end{array}$ \\
\hline 11 & My favorite food & $\begin{array}{l}\text { Burger, cake, milk, ice cream, tea, fried chicken, potato, candy, } \\
\text { noodle }\end{array}$ \\
\hline 13 & My family & $\begin{array}{l}\text { Head, eyes, ears, shoulders, nose, mouth, neck, hair, hand, arm, } \\
\text { fingers, leg, knee }\end{array}$ \\
\hline
\end{tabular}

Peneliti hanya mengambil 4 unit terakhir pada pembelajaran di semester dua yang tentunya mengaplikasikan active learning. Media pembelajaran yang digunakan adalah menggambar dan mewarnai, flash card, objek nyata, serta kartu bundar.

\section{Pendekatan Active Learning}

Setiap kegiatan pembelajaran sudah selayaknya melibatkan siswa secara aktif. Kebenaran pernyataan tersebut tidak dapat terelakkan. Active learning merupakan sebuah upaya pembaharuan yang dioptimalkan dalam aktifitas pendidikan. Pendekatan ini memang masih terbilang baru, namun pada kenyataannya konsep ini sudah sejak lama dikembangkan.

Dikarenakan fakta tersebut, mendefinisikan active learning menjadi sedikit sulit. Namun Sukandi dkk (2001:6) menyatakan bahwa pendekatan ini merupakan sudut pandang yang meyakinkan bahwa pemahaman yang diperoleh dari sebuah aktifitas belajar adalah bentuk pencapaian dari sebuah pengalaman yang dilalui. Artinya informasi, wawasan, bahkan pengetahuan yang berhasil diperoleh seorang Vol. 1 No. 1, 2016 siswa bukanlah aktifitas yang didominasi oleh peran seorang guru. Oleh karena itu, pengajaran yang berlangsung dianggap sebagai sebuah upaya pembentukan suasana belajar yang dapat mengembangkan inisiatif dan tanggung jawab peserta didik. Dengan kondisi yang terbentuk, siswa tentunya akan memiliki semangat belajar sepanjang hidupnya, serta menjadi pribadi mandiri tidak bergantung pada kehadiran sosok pengajar atau hal lainnya ketika ingin mengenal sesuatu yang baru.

Gulo (2008: 74) memaparkan bahwa active learning adalah sebuah pendekatan yang melibatkan kegiatan siswa secara menyeluruh pada sebuah aktifitas pembelajaran, meliputi kegiatan mental, intelektual, emosional, dan fisik. Namun tentunya keterlibatan kegiatan tersebut harus tercipta dengan harmonis. Oleh karena itu, active learning akan menjadi sebuah pendekatan belajar yang membangun keterampilan siswa pada proses pemerolehan informasi atau pengetahuan.

Active learning yang tercermin pada sebuah kegiatan pembelajaran akan terbentuk 
berdasarkan aspek peserta, guru, dan suasana belajar. Siswa pada akhirnya harus menemukan dan mengalami secara langsung segala bentuk pengetahan yang akan disampaikan. Proses akan tercapai melalui interaksi dan komunikasi antar peserta didik, peserta didik dan guru, serta dengan sumber belajar. Guru pada pendekatan harus menjadi sosok yang terbuka, artinya harus mampu berbesar hati menerima masukan dari peserta didiknya. Guru juga harus bisa memberikan toleransi untuk kesalahan-kesalahan yang dilakukan siswa degan tidak lupa mengingatkan mereka untuk bisa memperbaikinya. Hal ini dilakukan sebagai upaya meningkatkan kepercayaan diri mereka. Pada akhirnya guru dianjurkan bisa memberikan sebuah penghargaan ketika peserta didiknya mampu menyelesaikan tugas dengan sempurna. Jika siswa mengalami sendiri proses pemerolehan pengetahuan, maka mereka akan lebih mudah menguasai dan memahami materi yang diajarkan, termasuk di dalamnya kegiatan penguasaan kosakata bahasa Inggris. Ingatan siswa akan terekam dengan baik dan tentunya kegiatan ini akan merangsang keingin tahuan mereka yang berdampak pada mningkatnya kreatifitas dan daya talar.

Raka Joni (1992: 19-20) menyebutkan bahwa proses pendekatan active learning memiliki karakteristik sebagai berikut:

- Pembelajaran yang terpusat pada siswa;

- Guru merupakan pengarah atau pembimbing dalam pemerolehan informasi;

- Tujuannya tidak hanya berorientasi pada ranah akademik;

- Aktifitas belajar cenderung menekankan kreatifitas siswa;
- Penilaian atau evaluasi yang dilakukan, ditujukan untuk mengkur dan mengamati tingkat perkembangan siswa.

(Dimyati, 2006: 120-121)

\section{Karakteristik Siswa SD}

\section{a. Karakteristik Psikologi Siswa SD}

Scott dan Ytreberg (2004) menyebutkan beberapa karakteristik pembelajar SD:

- Mereka belajar dari kegiatan yang dilakukan

- Mereka mampu menyampaikan sesuatu berdasarkan apa yang mereka lakukan dan dengar

- Mereka bisa dengan mudah memahami sesuatu

- Mereka memiliki ketahanan konsentrasi yang cenderung sedikit

- Mereka akan bahagia ketika bermaian dan melakukan sesuatu sendiri

- Mereka mampu bekerja sama dengan orang dewasa

- Mereka mempelajari bahasa Inggris dengan menggunakannya

- Mereka akan belajar dengan maksimal ketika termotivasi untuk terlibat langsung dengan kegiatannya yang sesuai dengan keinginan mereka

(Pabin \& Power, 1990: 8)

Dari paparan di atas, karakteristik siswa SD dapat dikenali berdasarkan aspek kognitif, sosial, dan emosional.

Pada aspek kognitif, anak-anak usia 7 tahun ke atas biasanya sudah mampu secara mental untuk memahami sebuah pengalaman. Namun kemampuan berpikir operasionalnya masih terbatas pada objek yang nyata atau sesuatu yang memang mereka alami langung. Oleh karena itu, Piaget menekankan anak-anak pada usia 7-11 tahun sebagai fase operasional. Pernyataan tersebut menjelaskan bahwa daya fikir mereka 
harus selalu dihubungkan pada sesuatu yang konkrit. Oleh karena itu, pada penelitian ini kegiatan pembelajaran akan menggunakan media gambar, objek nyata, bahkan sesuatu yang ada di ssekitarnya. Pada ranah ini juga, siswa memiliki semangat belajar yang tinggi. Sehingga guru akan sangat baik jika mampu memotivasi siswa untuk tetap semangat belajar. Namun perlu diwaspadai bahwa anak-anak pada usia ini cenderung banyak bicara. Oleh karena itu, pastikan dan ciptakan suasana belajar yang hanya mengizinkan mereka berbicara ketika memang diberi kesempatan. Hal ini tentunya dilakukan untuk mempertahankan situasi belajar yang kondusif dan efektif.

Pada aspek sosial, mereka biasanya masih labil ketika bersosialisasi. Mereka akan dengan dengan cepat menganggap seseorang teman, bahkan secepat kilat pula menganggap seseorang musuhnya. Mereka juga lebih memilih bergaul dan bermain dengan kelompok kecilnya. Dari sisi emosional, anak-anak pada usia ini terbangun menjadi sosok yang kritis. Mereka juga masih cenderung sulit menyikapi sebuah kegagalan. Singkatnya, karakteristik siswa SD akan dipengaruhi oleh proses pendewasaan, pembelajaran, serta minta dan bakat.

\section{b. Karakteristik Siswa Kelas 1 SDN Mulyasari 1}

Pada dasarnya karakteristik siswa di sekolah dasar ini sama seperti siswa di sekolah lain. Mereka sangat aktif dan interaktif. Mereka berani menyampaikan pendapat dan mengajukan pertanyaan ketika kegiatan belajar. Akan tetapi sering kali mereka berbicara pada saat yang kurang tepat.

Kerja keras harus selalu dilakukan untuk mengelola kelas ini, karena masih ada beberapa siswa yang sulit konsentrasi dan mengontrol diri. Beberapa metode akan dibutuhkan untuk tetap memotivasi semangat mereka. Mereka akan

Vol. 1 No. 1, 2016 mampu menyelesaikan sesuai, jika diberi pemahaman atas pentingnya informasi tersebut, tentunya diperkuat dengan penekanan verbal dan non-verbal.

\section{Metodologi}

\section{Tempat dan Waktu Pelaksanaan} Penelitian

Penelitian ini dilaksanakan di kelas 1 SDN Mulyasari 1, Bandung. Yang berlokasi di jalan Cigaitri Desa Lengkong Kec. Bojongsoang Kab. Bandung. Penelitian ini berlangsung pada semester 2 tahun akademik 2009/2010, dari bulan Maret sampai Juni 2010. Kegiatan yang dilakukan meliputi persiapan, pelaksanaan, dan pelaporan.

\section{Metode dan Model Tindakan}

Penelitian tindakan ditujukan untuk mengoptimalkan dan meningkatkan efektifitas kegiatan pembelajaran. Mengingat penelitian tindakan ini dilakukan di kelas, maka metode yang digunakan adalah Penelitian Tindakan Kelas (PTK). Implementasi penelitian ini berdasarkan pada kalender akademik yang berlangsung di SDN Mulyasari 1, yaitu 2 jam pelajaran setiap minggunya. Model tindakan yang diambil adalah model Kurt Lewin yang terdiri dari 1. Perencanaan, 2. Tindakan, 3. Pengamatan, dan 4. Refleksi.

\section{Subjek Penelitian}

Subjk penelitian ini adalah 25 siswa kelas 1 SDN Mulyasari 1, Bandung. Terbagi menjadi 12 siswa dan 13 siswi. 2 orang wali kelas dilibatkan menjadi pengamat selama pengimplementasian active learning, atas nama Een Nuraeni, S.Pd.I. dan Nani Rohaeni, S.Pd.I. 


\section{Peran dan Posisi Peneliti}

Peneliti memegang peranan utama, yang harus bisa merefleksikan proses pembelajaran bahasa Inggris di kelas dan membuat perencanaan tindakan yang akan diterpakan di kelasnya. Oleh karena itu, peneliti akan merasakan, melakukan, dan mereflksikan pembelajaran yang sudah dilakukan untuk pengembangan kelasnya. Peneliti juga menuliskan catatan lapangan sepanjang penelitian.

Siklus I

\section{Langkah-langkah Intervensi Tindakan}

\begin{tabular}{|l|l|}
\hline Refleksi & $\begin{array}{l}\text { Guru melakukan refleksi terhadap pembelajaran yang sudah } \\
\text { terlaksana, termasuk didalamya cara guru mengajar, cara siswa } \\
\text { belajar, suasana belajar, dan memikirkan perbaikan-perbaikan } \\
\text { yang tepat. }\end{array}$ \\
\hline Perencanaan Tindakan & $\begin{array}{l}\text { Membuat rencana pembelajaran dengan mengaplikasikan active } \\
\text { learning. }\end{array}$ \\
\hline Penerapan Tindakan & $\begin{array}{l}\text { Guru mengaplikasikan pembelajaran bahasa Inggris } \\
\text { menggunakan active learning. }\end{array}$ \\
\hline Pengamatan & $\begin{array}{l}\text { Para pengamat, dalam hal ini wali kelas, mengamati dan } \\
\text { mengevalauasi kegiatan belajar yang berlangsung dengan mengisi } \\
\text { kolom angket yang sudah disediakan. }\end{array}$ \\
\hline Refleksi & $\begin{array}{l}\text { Guru menelaah dengan baik hasil pengamatan, evaluasi, dan } \\
\text { catatan lapangan untuk menentukan langkah berikutnya. }\end{array}$ \\
\hline
\end{tabular}

Siklus II

\begin{tabular}{|l|l|}
\hline Perencanaan Tindakan & $\begin{array}{l}\text { Guru membuat rncana perbaikan berdasarkan hasil refleksi dan } \\
\text { pengamatan pada siklus I. }\end{array}$ \\
\hline Penerapan Tindakan & Guru mengajar berdasarkan rencana perbaikan pada siklus I. \\
\hline Pengamatan & Mengamati dan mengevaluasi kemajuan atas penerapan tindakan. \\
\hline Refleksi & $\begin{array}{l}\text { Guru menelaah dengan baik hasil pengamatan, evaluasi, dan catatan } \\
\text { lapangan untuk menentukan hasil penelitian pada ke dua siklus yang } \\
\text { sudah dilampaui. }\end{array}$ \\
\hline
\end{tabular}

\section{Tujuan Intervensi Tindakan}

Tujuan dari setiap tindakan yang dilakukan pada proses pembelajaran kosakata bahasa Inggris berorientasi pada kemajuan penguasaan kosakata dan hasil belajar yang tercermin pada lembar tugas dan tes formatif.

\section{Data dan Pengumpulan Data}

Data pengamatan digunakan untuk mengontrol kesesuaian implementasi tindakan dengan rencana tindakan, pada kasus ini berkaitan dengan aplikasi active learning. Data yang diperoleh dari hasil belajar digunakan untuk menganalisa kemajuan penguasaan kosakata bahasa Inggris siswa. Oleh karena itu sumber 
data diperoleh melalui 2 bagian, yaitu data dari pengamat penelitian dan dari hasil belajar siswa (lembar tugas dan tes formatif).

\section{Teknik Pengumpulan Data dan Instrumen yang Digunakan}

Pengumpula data dilakukan dengan menggunakan instrumen pembelajaran yang didalamnya termasuk cara guru mengajar, cara siswa belajar, dan suasana belajar. Komponen tersebut tentunya sangat berkaitan erat dengan konsep active learning. Disamping itu instrumen tes digunakan sebagai cermin yang mengilustrasikan hasil penguasaan kosakata bahasa Inggris siswa. Tes yang disusun berdasar pada kurikulum 2006 dan buku ajar active English. Bentuk tes adalah 10 pertanyaan pilihan ganda.

\section{Teknik Validasi}

Triangulasi digunakan untuk memastikan validitas data. Lather (Priyono, 2000:11) memaparkan bahwa triangulasi ini merupakan cara penentuan sesuatu berdasarkan beberapa sudut pandang. Artinya validasi ini akan mencakup hasil pengamatan dan catatan lapangan pengamat yang akan digabungkan dengan pengalaman yang dirasakan juga oleh peneliti. Tentunya untuk mengetahui penguasaan kosakata, dapat diperoleh melalui hasil lembar tugas dan tes formatif.

\section{Analisa Data dan Interpretasi Hasil Analisis}

Analisis data yang dilakukan berdasarkan pada pengamatan terhadap keterlibatan siswa pada proses belajar, sikap guru ketika mengajar dengan pedekatan active learning, dan hasil belajar siswa. Dengan mengaplikasikan pendekatan ini, siswa diharapkan bisa menjadi lebih aktif dalam mengikuti kegiatan belajar. Guru bukanlah satusatunya sumber belajar, tetapi juga bisa menjadi teman dan pendamping. Oleh karena itu, siswa akan mampu menguasai bahasa Inggris dengan baik.

\section{Hasil Penelitian}

\section{a. Siklus I}

Dari siklus I, hasil yang diperoleh guru masih kurang terbuka dan belum bisa memunculkan inisiatif dan kreatifitas belajar. Guru juga masih kurang melibatkan siswa pada kegiatan belajar berkelompok, karena hanya sebagian siswa saja yang antusias dan melakukan instruksi yang diberikan. Kondisi guru nampaknya masih diselimuti kecemasan terhadap hasil belajar siswa. Sikap ini terlihat dari sikap guru yang sering terburu-buru membantu siswa jika ada kesulitan dan kurang memberikan kesempatan mereka untuk berkomunikasi. Suasana belajar seperti ini tidak menyenangkan bagi siswa, sehingga inisiatif dan kreatifitas belajar menjadi sulit digali.

Dengan kata lain, kegiatan pembelajaran yang seharusnya terpusat pada siswa masih didominasi oleh guru. Padahal ada 2 target yang harus tercapai pada kegiatan active learning, yaitu pembelajaran yang terpusat pada siswa dan mereka bisa belajar dengan senang. Mereka juga diharapkan bisa mandiri, memecahkan masalah sendiri, dan merefleksikan kegiatan yang dilakukan. Guru hanya berperan sebagai motivator, yang memberikan klarifikasi terkait dengan materi yang diajarkan.

Hasil kegiatan belajar mengajar mencapai rata-rata 7.74 untuk lembar tugas dan 8.78 untuk tes formatif. Suasana belajar yang tercipta sebesar $65.25 \%$ dan pengamatan terhadap performa guru sebesar $80 \%$. Sedangkan hasil analisis pengajaran kosakatanya sebesar 75\%. Hasil-hasil tersebut memerlukan perbaikan pada siklus berikutnya. 


\section{b. Siklus II}

Sikap dan kegiatan siswa serta guru pada aktifitas belajar di siklus ini sudah menggambarkan peningkatan keingintahuan siswa melalui pendekata active learning. Interaksi dan komunikasi sudah muncul, tidak hanya antara siswa dengan guru tetapi juga antar siswa. Nampak juga keharmonisan yang meliputi kemampuan sosial, emosional, dan intelektual. $\mathrm{Hal}$ ini tentunya akan meningkatkan potensi yang ada.

Kegiatan belajar sudah terpusat pada siswa. Guru berperan sebagai perangsang agar siswa memiliki motivasi untuk belajar, sportif, dan mampu memperbaiki kesalahan sehingga mampu menguasai kosakata bahasa Inggris dengan baik. Dari 4 pertemuan yang sudah dilakukan pada siklus ini sudah menunjukkan kegiatan guru dan siswa yang diharapkan sebagai dampak dari penerapan active learning.

Hasil kegiatan belajar mengajar mencapai rata-rata 8.06 untuk lembar tugas dan 8.96 untuk tes formatif. Suasana belajar yang tercipta sebesar $80.00 \%$ dan pengamatan terhadap performa guru sebesar 90\%. Sedangkan hasil analisis pengajaran kosakatanya sebesar $85 \%$. Hasil-hasil tersebut sudah memenuhi standar ideal yang ditentukan oleh peneliti.

\section{Simpulan}

Hasil penelitian ini menunjukkan bahwa penguasaan kosakata bahasa Inggris melalui active learning mampu melibatkan kemampuan social, emosional, dan intelektual dengan harmonis. Sehingga siswa mampu meningkatkan potensinya, merangsang daya pikirnya, dan menyelesaikan masalah sendiri. Disamping itu ketika pengaturan siswa dan pemilihan metode yang sesuai dengan materi yang akan diajarkan dan karakteristik siswa kelas 1 akan menciptakan komunikasi dan interaksi antara siswa dan guru, bahkan antar siswa. Maka dari itu, siswa mampu memaparkan informasi yang mereka peroleh kepada orang lain dan melatih keberanian serta kepercayaan diri mereka.

Belajar melalui penerapan active learning dapat meningkatkan penguasaan siswa, karena pada dasarnya mereka memang suka belajar, bekerja, dan melakukan beragam kegiatan. Segala bentuk informasi yang mereka peroleh dengan melakukan, mencari, dan menemukan sendiri akan mengasah kemampuan dalam mengingat. Siswa juga akan senang jika terlibat pada suatu kegiatan. Melalui active learning ini mereka bisa mengembangkan potensi dan kapasitas mereka. Mereka juga bisa mengasah kemampuan berpikir kritis. Hal ini terbukti dari hasil penelitian yang menunjukkan bahwa lebih dari setengah jumlah siswa di kelas terlibat dalam kegiatan belajar bahkan terlihat kemajuan mereka dalam penguasaan kosakata bahasa Inggris. Siswa dengan penguasaan yang baik akan mampu menjadi tutor sebaya, dalam hal ini sagat berpengaruh terhadap penguasaan kosakatanya.

\section{Rekomendasi}

Berdasarkan hasil penelitian yang sudah diperoleh, peneliti merekomendasikan para pengajar untuk menggunakan active learning dalam proses belajar mengajar, karena pendekatan ini sangat sesuai dengan karakteristik siswa SD. Mereka disarankan untuk bisa meningkatkan kinerja melalui pengembangan kreatifitas guru dalam menyusun aktifitas belajar.

Lain halnya rekomendasi yang ditujukan kepada kepala sekolah. Kepala sekolah diharapkan mampu memotivasi guru, mendukung, dan senantiasa membimbing guru untuk mengimplementasikan active learning.

Bagi instansi dan pemerintah, peneliti merekomendasikan untuk berperan serta dalam pengembangan dan pembangunan alat serta 
infrastruktur pendidikan berdasarkan kebutuhan lapangan. Sedangkan rekomendasi untuk mahasiswa dan pembaca adalah untuk meneruskan penelitian ini guna memperoleh data yang lebih akurat.

\section{Daftar Pustaka}

Allen, Virginia French.(1983). Techniques in Teaching Vocabulary, London: Macmillan Press.

Alwasilah, A. Chaedar.(1997). Politik Bahasa dan Pendidikan, Bandung: Rosda.

Alwasilah, A. Chaedar.(2000).Pengajaran Bahasa Komunikatif, Bandung: Rosda.

Alwasilah, A. Chaedar.(2000). Perspektif Pendidikan Bahasa Inggris di Indonesia dalam Konteks Persaingan Global, Bandung: Andira.

Basrowi dan Suwandi.(2008). Prosedur Penelitian Tindakan Kelas Referensi Utama PTK untuk Guru serta Mahasiswa Keguruan dan Ilmu Pendidikan, Bogor: Ghalia Indonesia.

Brown, H. Douglas.(2008). Prinsip Pembelajaran dan Pengajaran Bahasa, Jakarta: Usembassy (Pearson Education, Inc).

Dewi, Ida Kusuma, dkk.(2008). Active English I, Solo: PT. Tiga Serangkai Pustaka Mandiri.

Dimyati dan Mudjiono.(2006). Belajar dan Pembelajaran, Jakarta: Rineka Cipta.

Finocchiaro, Mary.(1964). Teaching Children Foreign Language, New York: MoGraw-Hill Book Company.

Frandsen, Arden N.(1957). How Children Learn an Educational Psychology, New York: MoGraw-Hill Book Company, Inc.

Gulo W.(2008). Strategi Belajar Mengajar, Jakarta: PT. Gramedia Widiasarana Indonesia.

Hollingsworth, Pat \& Lewis, Gina.(2008). Pembelajaran Aktif, Jakarta: PT. Indeks.

Ihsan, H. Fuad.(2005). Dasar-dasar Kependidikan Komponen MKDK, Jakarta: Rineka Cipta.

Jarvis, peter.(1985). The Sociology of Adults and Continuing Education, USA: Croom Helm Ltd.

Manser, Martin H.(1995). Oxford Leraner's Pocket Dictionary, New Yrk: Oxford University Press.

Marlow, Rebecca- Fergson.(2002)World Education Encyclopedia a Survey of Educational System World wide Volume 2, Farmington Hills: Gale Gropu.

Musthafa, Bachrudin.(2002). EFL for Young Learners, Bandung: The Writing Team of Crest.

Procter, Paul.(1984). Longman Dictionary of Contemporary English, Great Britain: The Pitman Press.

Quirk, Randolph and Stein Gabriele.(1990). English in Use, England: Longman.

Scott, Wendy A and Ytreberg, Lisbeth H.(2004). Longman Keys to Language Teabing: Teaching English to

Children, USA: Longman, Inc.

Stern.(1983). Fundamental Concepts of Language Teaching, USA: Oxford University Pres.

Sudjana, Nana.(2009). Dasar-dasar Proses Belajar Mengajar, Bandung: Sinar Baru Algesindo.

Syah, Muhibbin.(1999). Psikologi Belajar, Jakarta: Logos.

Tarigan, Henry Guntur.(1986). Pengajaran Keterampilan Berbahasa, Bandung: Angkasa.

Tim Redaksi Fokusmedia.(2006). Guru dan Dosen, Bandung: Fokusmedia

Wallace, Michael J.(1987). Teaching Vocabulary, Great britain: English Language Book Society. 